\title{
Landscape structure changes in the Slepiotka River drainage basin in the period 1824-1993 (The Silesian Upland, Poland)
}

\begin{tabular}{|l|l}
\hline Kinga Mazurek & $\begin{array}{l}\text { Department of Physical Geography, Faculty of Earth Sciences, } \\
\text { University of Silesia, 60 Bedzinska Str., 41-200 Sosnowiec } \\
\text { mazurek.kingaa@ gmail.com }\end{array}$ \\
\hline
\end{tabular}

\begin{abstract}
The area of the Upper Silesian Coal Basin is the most important underground mining district in Poland. Coal mines, operating in the area since the eighteenth century, have contributed to massive transformations of the landscape structure. River valleys within range of intensive exploitation activities have been undergoing vast changes. The Slepiotka River drainage basin constitutes an interesting regional example of transformations in the river's watercourse as well as in its adjacent area. It is a left-hand tributary of the Klodnica River with a length of about $8.6 \mathrm{~km}$.

Changes in the landscape structure that occurred between 1824-1993 have been analyzed. The starting material consisted of topographical maps that were digitized and calibrated and served as a basis to create colorful compositions. The areas occupied by the different land cover types have been calculated, which allowed to determine their participation in the drainage basin.

In about 169 years, significant changes took place in the area of research considering the share of different types of cover and land use. During this time, the river changed its course, both naturally and by human activities. Increasing urbanization and technological development contributed to the diametrical transformation of the landscape structure in the discussed area.
\end{abstract}

Key words: land use, structure of the landscape, the Slepiotka River drainage basin, Katowice, GIS, topographic map

DOI: $10.2478 /$ ctg-2014-0020

Received: $26^{\text {th }}$ June, 2014

Accepted: $1^{\text {st }}$ September, 2014

\section{Introduction}

Landscape, understood as an area characterized by a specific physiognomy, which is dynamic and subject to the evolution of the system, is continuously modified as a result of increasing human activities (Richling \& Solon 1994). The Upper Silesian Coal Basin (USCB) environment transformations are contributed to the progressing urbanization and the intensive exploitation of coal. The effects of excessive human pressure are manifested by changes in the landscape structure. It takes on the characteristics of a cultural landscape, which is a landscape transformed by people as a result of the progress of civilization (Myga- Piątek 2010). Significant modifications occur within river basins located in mining areas. A comparison of archival and contemporary states of the landscape in the area of research, as well as the observation of current transformations and their trends allows for the assessment of transformations. The aim of this paper is to determine transformations of landscape structure in the area of the Slepiotka River drainage basin, which is a typical example of changes in the manner of use and coverage of riparian areas in the Upper Silesian Metropolitan Union. 


\section{Study area}

The Slepiotka River is a small left-hand tributary of the Klodnica River (the Oder tributary). The whole course of the Slepiotka River is located within administrative boundaries of the city of Katowice (Fig. 1). The river discharges water from the Murcki Plateau. Its sources are in the forests on the border of the Murcki and Ochojec districts, at an altitude of $308 \mathrm{~m}$ above sea level. Its watercourse is only $8.6 \mathrm{~km}$, and the drainage basin area consists of $13.86 \mathrm{sq} \mathrm{km}$. The river flows into the Klodnica in the district of Panewniki-Wymyslow. The Slepiotka's mouth is located at an altitude of $251 \mathrm{~m}$ above sea level (Hydrographic map of Poland 1:50 000, Trząski et al. 2000).

The examined drainage basin is located in the central part of the Upper Silesian conurbation. According to the geophysical regionalization by Kondracki (2002), this area belongs to the Silesian Upland macro-region (341.1) and the Katowice Upland mesoregion (341.13). The area is largely built by Upper Carboniferous sandstones and coal-bearing slates, with arrears of tertiary sandstones, clays and gypsum and quaternary sediments (sands and clays) (Kondracki 2002).

Taking into account geomorphological regions developed by Karas-Brzozowska (1960), the drainage basin is located in the Katowice Plateau in the Klodnica Trench. As a result of Hercynian and Alpine tectonic movements, the terrain became of horst character. The area has a relief of a typical bottom of valleys and basins as well as plateaus (Gilewska 1972, Pelka-Gościniak \& Szczypek 2008). The relief has been modified as a result of mining and urbanization.

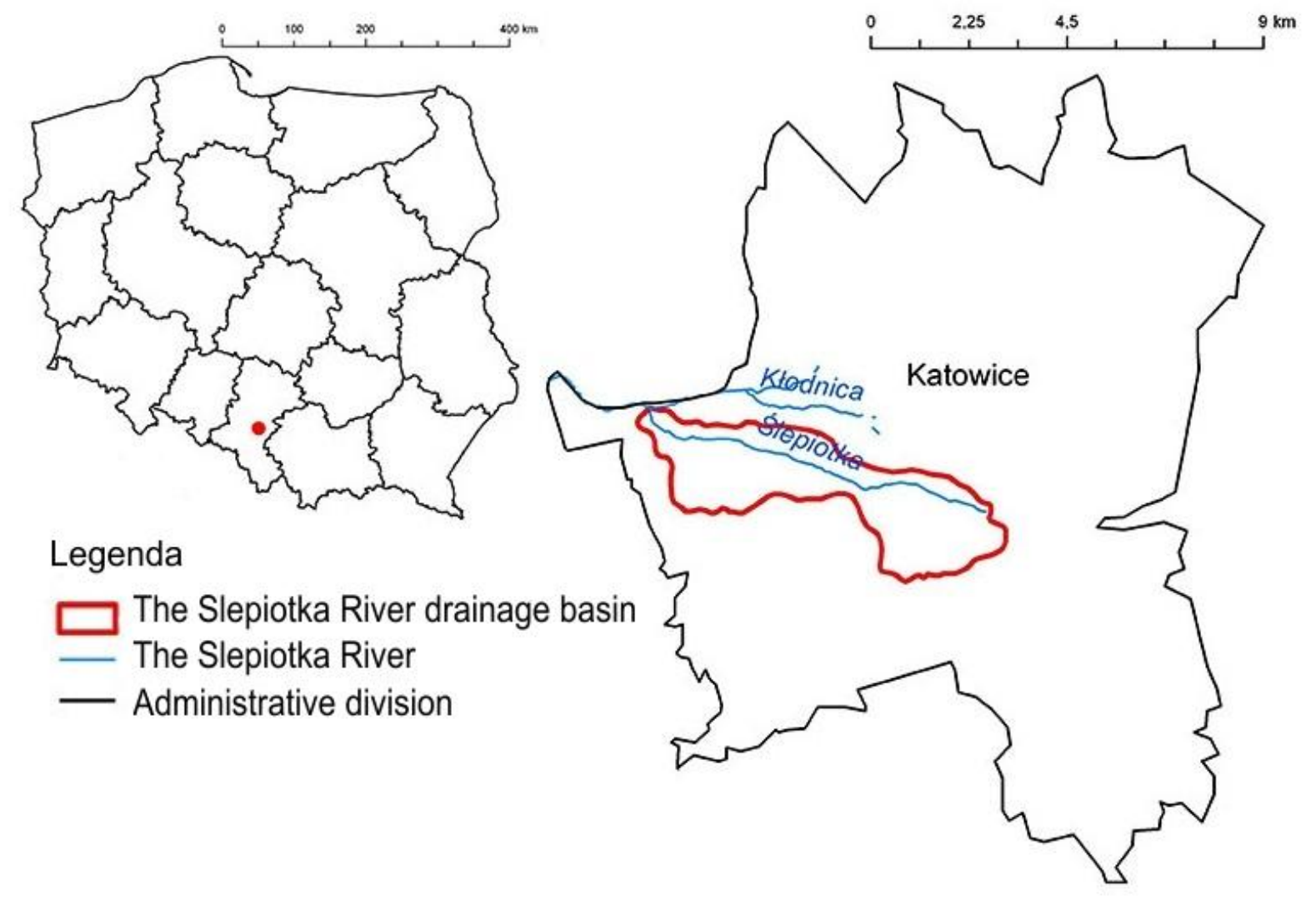

Fig.1. The location of the Slepiotka River in Poland and in the city of Katowice. 
In the area of research there are acidic and podsolic soils, originating from sands and clays, and hydrogenic silty-marsh soils, typical for moist grounds. The soils in areas heavily transformed by human exhibit characteristics of anthropogenic - industrial soils and urban soils (Dobrzyński et al. 1999, Konecka-Betley et al. 1999).

The drainage basin area is a habitat for over 1,000 species of flora. The area is mainly covered by mixed woodland species composition: red oak (Quercus rubra), birch (Betula), larch (Larix), aspen (Populus tremula) and black alder (Alnus glutinosa) (Gierlotka 2002). The lower and the watersource sections of the valley are covered by deciduous and mixed forests. The valley enters the precincts of the Ochojec Nature Reserve, with the protected species of Streptopus amplexifolius, largest number of plants growing outside of mountain areas and also the Allium ursinum. The backwaters of the river, wet meadows and reservoirs are conducive to the development of water plants vegetation. In addition, synanthropic (ruderal and segetal) and nitrophilous vegetation is highly represented.

The middle course of the river runs through heavily urbanized areas and the reclaimed heaps of the "Murcki" coal mine (Topographic map 1:10 000).

\section{Materials and methods}

The analysis concerned a basic observation of the drainage basin of the Slepiotka River. The aim of the study was to demonstrate transformations of the local landscape that emerged in the period 1824-1993 (169 years). The research is based on two time frames, the paper, however constitutes a fragment of a broader analysis based on more numerous, and shorter periods of time.

The first stage consisted in the summary and comparison of cartographic materials. The following topographical maps constituted source materials: the Urmesstischblatt Prussian official map in the scale of 1:25000 from 1827 (field measurements were taken in 1824) and a map in the scale of 1:10 000 from 1994 (presenting the field state of 1993). In addition, a hydrographic map of Poland 1:50 000 (2001) was used as well. Cartographic materials have been calibrated and transformed to a common coordinate system - the UTM System (WGS 1984 Transverse Mercator). Maps of the nineteenth century were calibrated with manually applied checkpoints. Due to the large time discrepancy, sacred buildings, characteristic junctions of transportation routes and map corners were chosen as points of convergence (Szymura et al. 2010).

The study area was marked out on the basis of the hydrographic map of Poland 1:50 000, according to the course of the $3^{\text {rd }}$ category watershed for the Slepiotka River. The boundaries of the Slepiotka drainage basin are partially divergent to the watershed that had been designated on the basis of the cartographic material from 1827 . This is due to the mining activity, which has significantly affected the subsidence of land and, consequently, its significant reduction in the height above sea level (Dulias 2011). To standardize the research area, a division shown on the hydrographic map of Poland was adopted.

Materials were prepared with the use of Geographic Information Systems (GIS) ArcGIS 10.2 by ESRI. A set of grounds and polylines was created that correspond with particular elements of landscape. Shapefile files have also been calibrated to the UTM System, enabling calculations of area. Categories of designated objects were aligned to the content of the map of 1827. On materials from the nineteenth century, forest areas were not divided into broadleaved and coniferous. Therefore, the following 6 ground categories were created: forests, meadows and unused land areas, wetlands and swamps, areas of organized vegetation (domestic vegetation, 
orchards, allotments, parks), built-up areas and reservoirs. Four types of objects were presented in the form of a polyline: the Slepiotka River and its tributaries, transportation routes (major transportation routes for 1993) and railway lines. In the case of materials from the nineteenth century, the main division of land is ambivalent - either as a forest area or a non-forest area. In preparing the materials from the twentieth century, a unification of areas was applied: deciduous forest, coniferous forest, shrubbery, sparse forest, dwarf pine forest; it needs to be noted that single trees were not taken into account. Individual area and linear structures were marked manually. Based on the prepared components, colorful compositions were created, depicting the state of geographical environment in the years 1824 and 1993 in the drainage basin of the Slepiotka (Fig. 2). Percentage changes in the structure of the landscape were calculated to illustrate the scale and direction of environmental transformations.

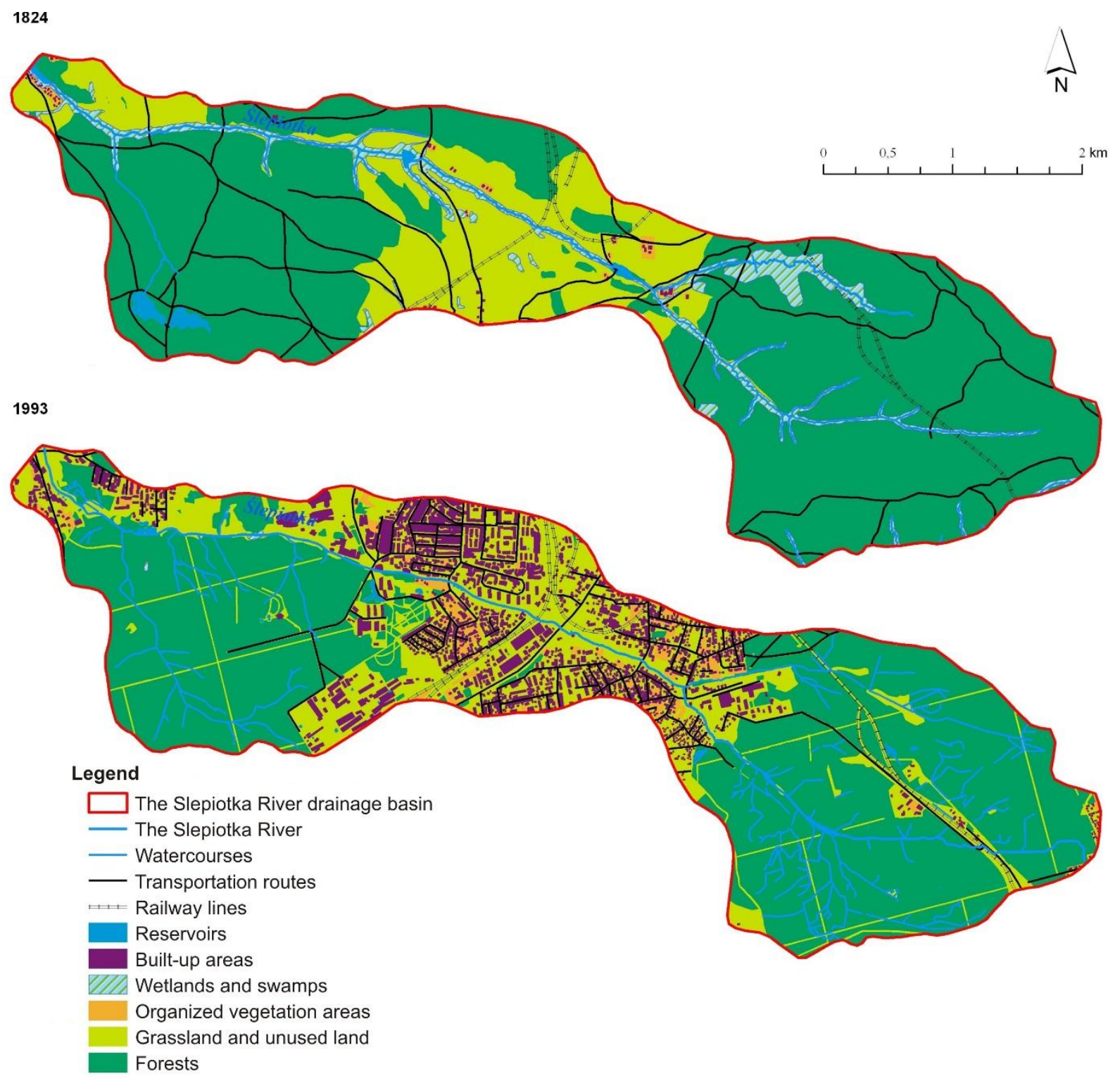

Fig.2. The structure of land use in the drainage basin of the Slepiotka. 


\section{Results}

In the period of almost 170 years of the use of the Slepiotka drainage basin, significant changes have occurred. The contemporary landscape of the valley clearly deviates from the landscape of the early nineteenth century. Detailed data evaluating the changes in land cover of the examined area are summarized in Table 1. There has been a significant decrease in area occupied by forests, with a simultaneous significant increase in the builtup area. In 1824, forest vegetation covered $10.23 \mathrm{sq} \mathrm{km}$, which constituted as much as $71.09 \%$ in relation to the area of the whole Slepiotka drainage basin (13.86 sq km). After 169 years, this area decreased to $8.36 \mathrm{sq} \mathrm{km}$ (60.31\% of the total drainage basin area). Built-up areas with residential buildings, utility and cubature facilities have increased by $8.13 \%$. In 1824, built-up areas occupied 0.02 sq $\mathrm{km}$, whereas in $1993-1.15 \mathrm{sq} \mathrm{km}$. This type of land use has increased nearly 58 times. The phenomenon of sprawl in urban areas with the simultaneous shrinking of forest areas is particularly evident in the central and northwestern parts of the research area. It is associated with significant increase in human settlements as a result of an influx of large numbers of people to a developing city. It should be noted that initially there were only 65 buildings in the researched basin. In the twentieth century, the settlement network grew to a very large size. The districts of Panewniki and Ochojec have developed in this area. The next category of land use - grassland and unused land - also reported a significant increase (from $2.77 \mathrm{sq} \mathrm{km}$ in 1824 to $4.07 \mathrm{sq}$ $\mathrm{km}$ in 1993). The increase in the share of grassland and unused land in the drainage basin area during the period of nearly 170 years was $10.93 \%$. This fact can be explained by including in it former woodland, with no activity conducted on it presently (e.g. post- industrial areas). Together with the development of settlement, the area of organized vegetation has increased, which includes groups of urban and backyard vegetation and various orchards and allotments. This category has increased from $0.42 \%$ to $1.66 \%$ (from $0.06 \mathrm{sq} \mathrm{km}$ in 1824 to $0.23 \mathrm{sq} \mathrm{km}$ in 1993). Areas occupied by reservoirs and wetlands and marshes have decreased. Five reservoirs existing in 1824 covered $0.69 \%(0.1 \mathrm{sq} \mathrm{km})$. In the year 1993 , despite an increase in the number of hydrographic objects, the total area amounted to $0.32 \%$ (0.04 sq km). Marshy wetlands have changed enormously and during the period, they decreased by as much as $9.20 \%$ (from $1.44 \mathrm{sq} \mathrm{km}$ in 1824 to $0.007 \mathrm{sq} \mathrm{km}$ in 1993). During this time, the Slepiotka River changed its course, both naturally and by human activities. Old river beds and meanders were being formed and later evolved, rivers were regulated through irrigation channels. Watercourses have also been modified. The number of rivers and canals that drained the area of research has significantly increased, which resulted in an increase in their total length from $11.32 \mathrm{~km}$ to $36.41 \mathrm{~km}$. This fact is associated with the ongoing drainage treatments.

Linear objects (transportation routes and railways) have developed considerably. As shown in the cartographic material from 1827, no railway line ran through the research area and all lines of transportation accounted for the total of $36.11 \mathrm{~km}$. After 169 years of infrastructure development, the railway in the basin has $7.66 \mathrm{~km}$ (excluding railway junctions), and there are over $40 \mathrm{~km}$ of transportation routes (roads included here are of higher rank, paved or asphalt surface).

Modification of the landscape has influenced changes in the area and condition of the Lubinowski Forest (the Silesian Forest). Surrounding marshes have been almost 
completely destroyed. Forest areas have been depleted, drained and converted into land covered with herbaceous vegetation or built-up areas and remodeled as a result of coal mining and storage of post-mining and post-steelworks waste.

Most pronounced changes in land use have been observed in the central part of the basin, i.e. in the district of Ochojec. Here, the settlement network has evolved considerably. It used to be just a few buildings that have grown to the size of a large district. Also, a settlement located in the north-western part of the research area has developed, which constitutes a part of the Panewniki district. Forest areas within the Panewniki and Murcki districts have been largely preserved. Forest areas are not longer exposed to a significant decrease. Moreover, environmental protection is maintained for example in the form of the Ochojec Nature Reserve.

Tab.1. Land use in the Slepiotka River drainage basin

\begin{tabular}{rcc}
\hline $\begin{array}{c}\text { Ground } \\
\text { category }\end{array}$ & $\begin{array}{c}\text { Area as of 1827 } \\
{[\%]}\end{array}$ & $\begin{array}{c}\text { Area as of 1994 } \\
{[\%]}\end{array}$ \\
\hline $\begin{array}{r}\text { Forests } \\
\text { Meadows and } \\
\text { unused land } \\
\text { areas }\end{array}$ & 71.09 & 60.31 \\
$\begin{array}{r}\text { Wetlands and } \\
\text { swamps }\end{array}$ & 9.20 & 29.39 \\
$\begin{array}{r}\text { Areas of } \\
\text { organized } \\
\text { vegetation }\end{array}$ & 0.42 & 0.05 \\
$\begin{array}{r}\text { Built-up areas } \\
\text { Reservoirs }\end{array}$ & 0.14 & 1.66 \\
\hline Total & 0.69 & 8.27 \\
\hline
\end{tabular}

\section{Discussion}

Studies on changes in land use have also been conducted for other areas of the Upper Silesian Metropolitan Union (Czaja 1995, Czaja \& Rzętała 1999, Dulias 2010, Dwucet 2005, Gawenda et al. 2003). Described transformations of landscape structure have occurred in the area of the whole Upper Silesian conurbation. It should be noted that in the nineteenth century, vast expanses of land were typical of a single type of use. Then, many smaller forms of land cover have evolved within larger units. Individual landscape structure took the form of patches. Diversity that has developed within the old homogeneous units constitutes aim of further research on landscape structure.

The analysis referred to changes in the cultural landscape. An examination of the landscape structure in terms of chronostructure, leads to interesting results which can be illustrated and interpreted in a variety of ways. The structure of the landscape is a specific group of components that make up the landscape and the relationships between them (Kondracki \& Richling 1983).

Recognition of changes in land use is the first stage of the research on landscape structure. It is a starting point for the study of more complex issues. This study may be a prelude to a further, in-depth case study analysis. It is possible to further characterize the landscape through the use of landscape rating. The next step should be to analyze the model using a patch-corridor-matrix that determines the dynamics and transformation trends within the selected basin (Forman \& Gordon, 1986). The results may have significant applicatory importance in spatial planning with regard to the principles of sustainable development in areas of existing and projected impacts of mining.

A comparative analysis based on topographic maps allows an assessment of transformations in landscape components of the whole area or one selected category (Kunz \& Nienartowicz 2006). Access to cartographic materials is of great importance for the application and use of the analysis of landscape structure in a historical depiction. Contact with relevant sources that illustrate the state of geographical environment of the earlier 
centuries allows for the creation of interesting compositions and indicators. The quality and accuracy of maps and their precise calibrating is also significant. When performing a comparative analysis, categories of land should be unified by adjusting the aggregation of data to the contents of all materials (Kunz 2006).

\section{Summary}

The above study of topographic maps from 1827 and 1994 with the use of GIS tools, indicates significant changes in the landscape structure. A percentage summary of land cover outlines the direction and significance of the changes. The period of almost 170 years entails a specific urban and industrial leap, which has significantly transformed the structure of land use. At that time, a departure from the basic agricultural human activity took place, followed by a very intensive development of mining and heavy industry and a partial shift from industrial activities. The course of the Slepiotka River and its tributaries has been aligned. The drainage system has been expanded. The overgrown area covered by the Silesian Forest and occupied by local marshes and wetlands has undergone changes. Built-up areas, grassland, unused land and organized vegetation areas have developed. Transportation routes and railways have been expanded.

Access to archives and current cartographic materials of good quality allows to perform extensive analyses. To fully specify transformations that have occurred in the study area, a broader analysis based on landscape metrics should be applied. In addition, it is necessary to unify and define categories listed in the legend. A more extensive legend, with more categories, would enable a detailed recognition of landscape transformations. It should, however, be taken into consideration that the materials needed to have been adapted to the oldest materials whose content is limited.

\section{References}

Czaja S. (1995) Changes in land use and the surface hydrographic network in the city of Katowice in the period 1801-1985. Geographia Studia et dissertationes, 19. UŚ. Katowice (In Polish: Zmiany użytkowania ziemi i powierzchniowej sieci hydrograficznej na obszarze miasta Katowice w latach 1801-1985).

Czaja S., Rzętała M. (1999) Changes in land use and the surface hydrographic network in the city of Chorzow from the late eighteenth century to the present day. [In:] Kapała Z. (red.) Zeszyty Chorzowskie 3, Chorzow (In Polish: Zmiany użytkowania ziemi

i powierzchniowej sieci hydrograficznej na obszarze miasta Chorzowa od końca XVIII wieku do czasów współczesnych).

Dobrzyński B., Konecka-Betley K., Kuźnicki F., Zawadzki S. (1999) Soil map of Poland 1:2 000 000. PWRiL, Warsaw.

Dulias R. (2010) The influence of mining on landscape of „Żabie Doły” (Silesian Upland). Kształtowanie środowiska geograficznego i ochrona przyrody na obszarach uprzemysłowionych i zurbanizowanych, 41. UŚ, WBiOŚ, WNoZ. Katowice-Sosnowiec: 5-12 (In Polish: Wpływ górnictwa na krajobraz „Żabich Dołów” (Wyżyna Śląska)).

Dulias R. (2011) Changes of relative heights in the area of Katowice over the last century. Kształtowanie środowiska geograficznego i ochrona przyrody na obszarach uprzemysłowionych i zurbanizowanych, 43. UŚ, WBiOŚ, WNoZ. KatowiceSosnowiec: 14-19 (In Polish: Zmiany wysokości względnych na obszarze Katowic w ostatnim stuleciu).

Dwucet K. (2005) Transformation of an industrial city landscape on the example of 
Chorzów (Province of Silesia). Postconference materials from II International Scientifically-Practical Conference titled "Industrial Heritage as a new product for tourism and recreation. National and international experiences". Zabrze 1213.05.2005r., GWSH, Urząd Miejski w Zabrzu: 79-84 (In Polish: Przekształcanie krajobrazu miasta przemysłowego na przykładzie Chorzowa (województwo śląskie). Materiały pokonferencyjne z II Międzynarodowej Konferencji Naukowo-Praktycznej pt. Dziedzictwo przemysłowe jako nowy produkt dla turystyki i rekreacji. Doświadczenia krajowe i międzynarodowe).

Forman R. T., Gordon M. (1986) Landscape Ecology. J. Wiley and Son. New York

Gawenda M., Machowski R., Rzętała M. (2003) Changes in land use in area of Ruda Śląska [In:] Jankowski A.T., Rzętała M. (red.) Ecological problems of Upper Silesian and Ostrava Industrial Region. Faculty of Earth Sciences University of Silesia, Sosnowiec: 34-45 (In Polish: Zmiany użytkowania terenu na obszarze Rudy Śląskiej)

Gilewska S. (1972) Silesian and Lesser Poland Uplands. [In:] Klimaszewski M. (ed.) Geomorphology of Poland. Volume 1. Southern Poland - mountains and highlands. Publication of PWN. Warsaw: 232-339 (In Polish: Wyżyny ŚląskoMałopolskie. Geomorfologia Polski. Tom 1. Polska południowa - góry i wyżyny).

Gierlotka S. (2002) Piotrowice Śląskie: a monograph of a district of Katowice. Publisher Śląsk. Katowice: 11-18 (In Polish: Piotrowice Śląskie: monografia dzielnicy miasta Katowice).

Hydrographic map of Poland 1:50 000, Sheets: M-34-62-B M-34-63-A, Surveyor General of Poland, Warsaw, 2001.
Karaś-Brzozowska
C.
(1960)

Geomorphological characteristics of the
Upper Silesian Industrial District. Bulletin of the Committee for the USID of the Polish Academy of Sciences, no. 37, Warsaw (In Polish: Charakterystyka geomorfologiczna Górnośląskiego Okręgu Przemysłowego).

Kondracki J. (2002) Regional geography of Poland. PWN- Scientific Publisher, Warsaw: 32-43, 243-256 (In Polish: Geografia regionalna Polski).

Kondracki J., Richling A. (1983) An attempt to organize terminology in the scope of comprehensive physical geography. Geographical Review 4, 1: 201-217 (In Polish: Próba uporządkowania terminologii w zakresie geografii fizycznej kompleksowej).

Konecka-Betley K., Kuźnicki F., Zawadzki S. (1999) Systematics and characteristics of Polish soils. Industrial and urban soils [In:] Zawadzki R. (ed.) Soil Science. PWRiL. Warsaw: 340-471 (In Polish: Systematyka i charakterystyka gleb Polski. Gleby industrio- i urbanoziemne. Gleboznawstwo).

Kunz M. (2006) Rectification and standardization of historical and modern cartographic data to land cover/land usage change analysis [In:] Wołoszyn W. (red.) Problemy Ekologii Krajobrazu. Zakład Ochrony Środowiska UMCS, Lublin, 18: 97-108 (In Polish: Rektyfikacja i standaryzacja historycznych i współczesnych danych kartograficznych do analiz zamian pokrycia/użytkowania terenu).

Kunz M., Nienartowicz A. (2006) Changes in land cover/land usage of Zaborski Landscape Park between 1796-2000 in the areas of various anthropopressure degree [In:] Wołoszyn W. (red.) Problemy Ekologii Krajobrazu. Zakład Ochrony Środowiska UMCS, Lublin, 18: 283-292 (In Polish: Zmiany pokrycia/uzytkowania terenu Zaborskiego Parku Krajobrazowego 
w latach 1796-2000 na obszarach o różnym stopniu antropopresji).

Myga-Piątek U. (2010) Transformations of cultural landscapes in the light of sustainable development ideas. Problemy Ekorozwoju 5, 1: 95-108 (In Polish: Przemiany krajobrazów kulturowych w świetle idei zrównoważonego rozwoju).

Pełka-Gościniak J., Szczypek T. (2008) The main features of the relief of the Upper Silesian Metropolitan Union and its transformations [In:] Dulias R., Hibszer A. (ed.) Upper Silesian Metropolitan Union. Geographical Outline. PTG Branch in Katowice. Sosnowiec: 34-42 (In Polish: Główne rysy rzeźby obszaru Górnośląskiego Związku Metropolitalnego i jego przekształcenia. Górnośląski Związek Metropolitalny. Zarys Geograficzny).

Richling A., Solon J. (1994) Landscape ecology. PWN- Scientific Publisher, Warsaw (In Polish: Ekologia krajobrazu).
Szymura T. H., Dunajski A., Ruczakowska A. M. (2010) Changes in forests surface in the area of Karkonosze National Park between 1747-1977. Opera Corcontia 47/2010 Suppl. 1: 159-166 (In Polish: Zmiany powierzchni lasów na obszarze Karkonoskiego Parku Narodowego w okresie 1747-1977).

Trząski L., Molenda T., Kupka. R. (2000) Land restoration of an urban stream - the programme for Ślepotka River [w:] „Problemy Ekologii”, nr 1, Wyd. Eco. Edycja, Katowice (In Polish: Renaturyzacja miejskiego potoku program dla Ślepiotki).

Topographic map of Poland 1:10 000, Sheets: M-34-62-B-d-1, M-34-62-B-d-2, M-34-62B-d-3, M-34-62-B-d-4, M-34-63-A-c-1, M-34-63-A-c-3, Surveyor General of Poland, Warsaw, 1994.

Urmesstischblatt 1:25 000, Sheets: 3353, 3354, 3391, 3392, 1827 